\title{
Influence of Azolla Extract and Mixed Media in Hydroponic Wick System on Caisin (Brassica juncea L.)
}

\author{
Sukuriyati Susilo Dewi \\ Department of Agrotechnology, \\ Faculty of Agriculture, \\ Universitas Muhammadiyah \\ Yogyakarta \\ Yogyakarta, Indonesia \\ Email: dewironny9999@yahoo.com
}

\author{
Agung Astuti \\ Department of Agrotechnology, \\ Faculty of Agriculture, \\ Universitas Muhammadiyah \\ Yogyakarta \\ Yogyakarta, Indonesia \\ Email: agung astuti@yahoo.com
}

\author{
Heni Herdiyanti \\ Department of Agrotechnology, \\ Faculty of Agriculture, \\ Universitas Muhammadiyah \\ Yogyakarta \\ Yogyakarta \\ Email: heniherdiyanti@yahoo.com
}

\begin{abstract}
The purpose of this research was to understand the influence of Azolla extract and mixed media in hydroponic Wick system on caisin and to find the best mix of organic nutrients in hydroponic Wick system on caisin. This research used an experiment with Single Factor Experiment in Completely Randomized Design consisting of 5 treatments of the mix of Azolla extract solution and various media, namely A: Azolla extract $200 \mathrm{ml} / \mathrm{I}+$ Husk charcoal $10 \mathrm{~g}+$ Vermicompost 94g, B: Azolla extract 200ml/l+ Husk charcoal $10 \mathrm{~g}+$ Azolla Compost 86g, C: Azolla extract 200ml/I + Husk charcoal $10 \mathrm{~g}+$ Vermicompost 47g + Azolla Compost 43g, D: Azolla extract $200 \mathrm{ml} / \mathrm{l}+$ Husk charcoal 20g, E: ABMIX + Husk charcoal 20g. The observation was done for 5 weeks, comprising of the measurement of plant height and number of leaves. At the end of the research period, the observation covered the measurement of root proliferation, root length, root fresh weight, plant dry weight, plant dry weight and leaf area. The results of the research showed the same results between inorganic nutrients and organic nutrients. The best combination of organic nutrients was C: Azolla extract 200ml/1 + Husk charcoal 10g + Vermicompost 47g + Azolla Compost 43g.
\end{abstract}

Keywords-Azolla extract, media, hydroponic Wick system, caisin

\section{INTRODUCTION}

Caisin not only needs macro and micro nutrients to support its growth, but it also relies on the progress of cultivation. Thus, farming technology has been advanced into hydroponic system that uses AB MIX nutrients to maintain stability in cultivating caisin.

Unfortunately, AB MIX nutrients is quite costly, so an alternative of AB MIX which contains similar nutrients is needed. Organic nutrients are supposed to be easily absorbed by plants and are more economically affordable. Nevertheless, these organic nutrients are usually still not as good as AB MIX nutrients. Therefore, additional nutrients are required to get optimal result.

Meanwhile, compost-based growing media have become preferences in hydroponic system. Hence, it is necessary to conduct deeper research on the effects of giving Azolla extract as organic nutrient and mixt of vermicompost and Azolla compost as additional nutrients to meet the nutritional requirement of caisin as a substitute of inorganic nutrients on hydroponic Wick system.

The purpose of this study is to know the effects of Azolla extract, media mixt, and determining the best organic nutrient mix in hydroponic Wick system on caisin.

\section{METHODS}

Materials

The materials used in this research were vermicompost, Azolla compost, Tosakan caisin seeds, husk charcoal, water, AB MIX nutrient solution and Azolla extract.

\section{Equipment}

The equipments required in this research were 1.5 liter bottle, axis, analytical scales, scales, measuring cups, ovens, scissors, cutter, labels, baskets, 30 liter bucket, air pump, seed tray with $12 \times 6$ holes, brown map, black spray paint, Muncell Color Chart, Leaf Area Meter (LAM) and root proliferation glass.

\section{Research Methods}

The study was arranged in a Completely Randomized Design with a Single Factor experiment consisting of 5 treatments of the mix of Azolla extract solution and various media, namely A: Azolla extract $200 \mathrm{ml} / 1+$ Husk charcoal $10 \mathrm{~g}+$ Vermicompost 94g, B: Azolla extract 200ml/1+ Husk charcoal 10g + Azolla Compost 86g, C: Azolla extract $200 \mathrm{ml} / 1+$ Husk charcoal $10 \mathrm{~g}+$ Vermicompost $47 \mathrm{~g}+$ Azolla Compost 43g, D: Azolla extract $200 \mathrm{ml} / \mathrm{l}+$ Husk charcoal 20g, E: ABMIX + Husk charcoal 20g.

\section{Time and Place}

This research was conducted from January to March 2016 in the Green House of the Faculty of Agriculture of Universitas Muhammadiyah Yogyakarta and analyzed in the Research Laboratory of the Faculty of Agriculture of Universitas Muhammadiyah Yogyarta, Tamantirto Village, Kasihan Subdistrict, Bantul Regency, Special Province of Yogyakarta. The media mixtures used are as follows: A: Azolla extract $200 \mathrm{ml} / 1+$ Vermicompost $94 \mathrm{~g}+$ Husk charcoal $10 \mathrm{~g}, \mathrm{~B}:$ Azolla extract $200 \mathrm{ml} / 1+$ Azolla compost $86 \mathrm{~g}+$ Husk charcoal10 g, C: Azolla extract $200 \mathrm{ml} / 1+$ Vermicompost $47 \mathrm{~g}+$ Azolla Compost $43 \mathrm{~g}+$ Husk charcoal 10 g, D: Azolla extract $200 \mathrm{ml} / 1+$ Husk charcoal 20 g, E: 
$\mathrm{AB}$ MIX + Husk charcoal $20 \mathrm{~g}$. Each treatment was repeated 3 times to obtain 15 units. Each unit consisted of 3 sample plants and 2 reserve plants to obtain 75 units of observation (layout in Appendix 1).

\section{Management of Procedures}

This research began with a Preliminary Research (Determining the type of axis), followed by preparation of research including tools and planting materials, extracting Azolla, making hydroponic pot, preparing growing media, making nutrient solution.

\section{Planting and Maintenance}

This phase covered pest control and addition of nutrient and water solutions. The last stage was harvest with the parameters observed including Root length $(\mathrm{cm})$, Root Fresh Weight (g), Root Dry Weight (g), Root Proliferation, Caisin Plant Height (cm), Plant Fresh Weight (g) (G), Number of Leaves (Leaf), Leaf Area $\left(\mathrm{cm}^{2}\right)$, Leaf Color.

\section{Data Analysis}

Data from periodic observations were presented in histograms and graphs, while the final result was analyzed by analysis of variance using $F$ test with error rate $\alpha=5 \%$. In addition, the significant differences among treatments were tested further with Duncan Multiple Range Test (DMRT).

\section{RESULTS AND DISCUSSION}

\section{A. Root Development}

Table 1. Rate of Root Proliferation, Root Length, Root Fresh Weight and Root Dry Weight of Caisin

\begin{tabular}{ccrrr}
\hline Treatment & $\begin{array}{c}\text { Root } \\
\text { Proliferation } \\
(\%)\end{array}$ & $\begin{array}{r}\text { Root } \\
\text { Length } \\
(\mathbf{c m})\end{array}$ & $\begin{array}{r}\text { Root } \\
\text { Fresh } \\
\text { weight } \\
\mathbf{( g )}\end{array}$ & $\begin{array}{r}\text { Root Dry } \\
\text { weight } \\
(\mathbf{g})\end{array}$ \\
\hline A & 77 & 15.63 & 2.67 & 0.30 \\
B & 67 & 16.00 & 3.51 & 0.21 \\
C & 58 & 13.00 & 4.28 & 0.43 \\
D & 94 & 14.67 & 6.04 & 0.36 \\
E & 50 & 14.33 & 3.28 & 0.37 \\
\hline
\end{tabular}

Description: - Average numbers followed by different letters in one column indicate that there is a significant difference based on DMRT result at $\alpha=5 \%$.

- There is no significant difference based on the F-Specific test for root proliferation, a higher percentage indicates more root distribution.

A: Azolla extract $200 \mathrm{ml} / 1+$ vermicompost $94 \mathrm{~g}+$ husk charcoal $10 \mathrm{~g}$,

B: Azolla extract $200 \mathrm{ml} / 1+$ azolla compost $86 \mathrm{~g}+$ husk charcoal $10 \mathrm{~g}$

C: Azolla extract $200 \mathrm{ml} / 1+$ vermicompost $47 \mathrm{~g}+$ Azolla compost $43 \mathrm{~g}+$ husk charcoal $10 \mathrm{~g}$

D: Azolla extract $200 \mathrm{ml} / 1+$ husk charcoal $20 \mathrm{~g}$,

$\mathrm{E}: \mathrm{AB}$ MIX + husk charcoal $20 \mathrm{~g}$,

\section{Root Proliferation}

Based on the results of root proliferation measurement, the treatment of Azolla extract $200 \mathrm{ml} / 1+20 \mathrm{~g}$ husk charcoal had the highest root proliferation percentage of $94 \%$, followed by vermicompost treatment at $77 \%$. The availability of nutrients in the treatment of Azolla extract $200 \mathrm{ml} / 1+20 \mathrm{~g}$ of rice husk is very limited. In addition, the water binding capacity of husk charcoal and charcoal media is low compared with that of other treatments. In the condition of water shortage, most of the assimilations in plants that obtained from nutrition source will be distributed to the roots, so the roots can grow and meet the needs of the crops for water [1].

\section{Root Length}

The effects of organic nutrients on the root length were relatively the same. In addition, the root growth of hydroponic Wick system tends to grow laterally instead of growing downward [2]. This is supported by the results of root proliferation observations that had a significant percentage of root distribution due to the process of water and nutrient absorption in the hydroponic Wick system through the axis.

\section{Root Fresh Weight}

Based on the results of DMRT of root fresh weight, the treatment of Azolla extract $200 \mathrm{ml} / 1+$ husk charcoal $20 \mathrm{~g}$ showed the highest average root fresh weight of $6.03 \mathrm{~cm}$, different with other treatments. Root fresh weight is related to the amount of water in the roots, root length, and the number of roots in the plant [3] stated that roots grow intensively and laterally in nutrient-rich regions. Roots are able to respond to the distribution of nutrients and water.

\section{Root Dry Weight}

Based on the analysis results of the root dry weight, there were no significant differences among treatments. The average root dry weight was about $0.21 \mathrm{~g}-0.43 \mathrm{~g}$. Plant dry weight indicates the pattern of plant in accumulating photosynthetic products and its integration with other environmental factors, so that root dry weight is closely related to root biomass. According to [4] plant dry weight reflects the accumulation of organic compounds successfully synthesized by plants form inorganic compounds, especially water and carbon dioxide.

\section{B. Development of Shoot}

Plant growth and development are an important process in the life and development of a species. Growth and development take place continuously throughout the life cycle, depending on the availability of meristems, assimilation results, hormones and other growth substances, and a supportive environment [5]. Nutrient adequacy is very important for plant because it will affect plant growth. The use of various organic nutrients in hydroponic Wick system on caisin will affect plant growth in terms of plant height, plant fresh weight and plant dry weight.

Table 2. Plant height, Fresh Weight, Dry Weight, and Potential Yield of Caisin in the 5th week (End of Observation)

\begin{tabular}{lrrcr}
\hline \multirow{2}{*}{ Treatment } & $\begin{array}{r}\text { Plant } \\
\text { height } \\
(\mathrm{cm})\end{array}$ & $\begin{array}{r}\text { Plant } \\
\text { Fresh } \\
\text { weight }(\mathrm{g})\end{array}$ & $\begin{array}{r}\text { Plant dry } \\
\text { weight }(\mathrm{g})\end{array}$ & $\begin{array}{r}\text { Potensial } \\
\text { Yield } \\
(\text { ton/ha) }\end{array}$ \\
\hline
\end{tabular}




\begin{tabular}{crrrr}
\hline A & $23.83 \mathrm{ab}$ & $29.90 \mathrm{a}$ & $1.90 \mathrm{ab}$ & 3.3 \\
$\mathrm{~B}$ & $22.86 \mathrm{~b}$ & $20.43 \mathrm{~b}$ & $1.28 \mathrm{c}$ & 2.3 \\
$\mathrm{C}$ & $25.50 \mathrm{a}$ & $32.83 \mathrm{a}$ & $2.08 \mathrm{a}$ & 3.6 \\
$\mathrm{D}$ & $22.60 \mathrm{~b}$ & $19.60 \mathrm{~b}$ & $1.40 \mathrm{bc}$ & 2.2 \\
$\mathrm{E}$ & $25.67 \mathrm{a}$ & $30.83 \mathrm{a}$ & $1.64 \mathrm{abc}$ & 3.4 \\
\hline Description: & Average numbers followed by different letters in \\
one column & indicate there is a significant difference based on \\
DMRT results at $\alpha$ & $5 \%$ level.
\end{tabular}

A: Azolla extract $200 \mathrm{ml} / 1+$ vermicompost $94 \mathrm{~g}+$ husk charcoal $10 \mathrm{~g}$, B: Azolla extract $200 \mathrm{ml} / 1+$ Azolla compost $86 \mathrm{~g}+$ husk charcoal $10 \mathrm{~g}$, C: Azolla extract $200 \mathrm{ml} / 1+$ vermicompost $47 \mathrm{~g}+$ Azolla compost $43 \mathrm{~g}+$ husk charcoal $10 \mathrm{~g}$,

D: Azolla extract $200 \mathrm{ml} / 1+$ husk charcoal $20 \mathrm{~g}$, $\mathrm{E}: \mathrm{AB}$ mix + husk charcoal $20 \mathrm{~g}$,

\section{Plant Height}

In terms of plant height, there was a significant difference among treatments. Treatment A, C and E had the highest average plant height which was significantly different from those of other treatments. Plant vegetative growth is strongly influenced by the availability of macro nutrients $\mathrm{N}, \mathrm{P}$ and $\mathrm{K}$ and supported by sufficient micro nutrients. Vermicompost and Azolla compost also contain some plant hormones and microorganisms that are good for plant growth. According to [6] vermicompost contains growth regulators such as giberellin, cytokinin and auxin, as well as nutrients $\mathrm{N}, \mathrm{P}, \mathrm{K}, \mathrm{Mg}$ and $\mathrm{Ca}$ and Azotobacter sp which are non-symbiotic $\mathrm{N}$ elements bacteria that will help enrich the $\mathrm{N}$ elements needed by plants. The result of the effect of organic nutrients on the average caisin height during the observation in appendix 1 is shown in Graph 1.

\section{Plant Fresh Weight}

The canopy fresh weight can be seen in Table 2 indicating that Treatment $\mathrm{A}$ and $\mathrm{C}$ were not significantly different from treatment $\mathrm{E}$, but significantly different from other treatments. [7] stated that the fresh weight of plant canopy depends on the water contained in plant organs including stems, leaves and roots, so that the water content can result in a higher fresh weight of plant canopy. [8] mentioned that the number of leaves not only affects the leaf area but also affects the fresh weight of the plant canopy. The higher the number of leaves, the higher the fresh weight of canopy, the broader the leaf area of a plant.

\section{Potential Yield}

Based on the average yield of caisin, there were no significant differences among all the treatments. The potential yield of Taisakan caisin reached 150-250 grams / plant or 20 tons - 25 tons / hectare [9]. Based on these data, it is known that giving Azolla extract and mixed media had not yet reached the potential yield of caisin. A low potential yield was caused by some cultivation conditions using hydroponic wick system such as inability to support the best growth of plants because it cannot provide enough oxygen through rooting [10]. In addition, the hydroponic wick principle is static or passive because the nutrient solution is only stationary in one place so that after a long time, the nutrient solution will settle to the bottom of the nutrient container, resulting in a difficulty in absorbing the nutrients optimally [11]. These conditions resulted in non-optimal carrying capacity of the caisin so that the growth of these plants also became non optimal, preventing them from reaching the potential yields.

\section{Plant Dry Weight}

Shoot of the canopy dry weight showed no significant difference among treatment $\mathrm{A}, \mathrm{C}$ and $\mathrm{E}$ but there was significant difference from other treatments. Plant dry weight is affected by photosynthetic process that occurs in the plant. The accumulation of photosynthesis and the absorption of nutrients into organic compounds will form a plant biomass. The more the biomass of a plant, the better the metabolic process in the plant, and vice versa, a smaller biomass indicates an obstacle in the process of plant metabolism [12]. Leaf development is included as a major organ of the plant body. Related to that, the leaf has a leaf mouth structure (Stomata) which is useful for the exchange of $\mathrm{CO} 2, \mathrm{O} 2$, and water vapor from leaf to the nature and vice versa. According to [8], leaf observation is indispensable, in addition to being an indicator of growth, this also becomes supporting data to explain the growth process that occurs as in the formation of plant biomass.

Table 3. Average number of leaves and leaf area of caisin in the fifth dek

\begin{tabular}{|c|c|c|c|}
\hline Treatment & $\begin{array}{r}\text { Number of } \\
\text { Leaves }\end{array}$ & $\begin{array}{r}\text { Leaf Area } \\
(\mathrm{cm} 2)\end{array}$ & $\begin{array}{c}\text { Leaf Colour } \\
(\%)\end{array}$ \\
\hline $\mathrm{A}$ & $9.20 \mathrm{ab}$ & $302.67 \mathrm{~b}$ & 78 \\
\hline B & $7.33 \mathrm{c}$ & $227.00 \mathrm{~b}$ & 72 \\
\hline $\mathrm{C}$ & $9.70 \mathrm{a}$ & $397.00 \mathrm{~b}$ & 75 \\
\hline $\mathrm{D}$ & $8,13 \mathrm{~b}$ & $269.667 \mathrm{~b}$ & 67 \\
\hline $\mathrm{E}$ & $8.90 \mathrm{ab}$ & $388.67 \mathrm{~b}$ & 75 \\
\hline \multicolumn{4}{|c|}{$\begin{array}{l}\text { Description: - Average numbers followed by unequal letters in one } \\
\text { column indicate a real difference based on DMRT result at c } \\
5 \% \text {. } \\
\text { - Especially for Leaf Color, The higher percentage value } \\
\text { indicates the greener leaf color. }\end{array}$} \\
\hline
\end{tabular}

A: Azolla extract $200 \mathrm{ml} / 1+$ vermi compost $94 \mathrm{~g}+$ husk charcoal $10 \mathrm{~g}$, B: Azolla extract $200 \mathrm{ml} / 1+$ azolla compost $86 \mathrm{~g}+$ husk charcoal $10 \mathrm{~g}$, C: Azolla extract $200 \mathrm{ml} / 1+$ vermi compost $47 \mathrm{~g}+$ azolla compost $43 \mathrm{~g}+$ husk charcoal $10 \mathrm{~g}$,

D: Azolla extract $200 \mathrm{ml} / 1+$ husk charcoal $20 \mathrm{~g}$, $\mathrm{E}: \mathrm{AB}$ MIX + husk charcoal $20 \mathrm{~g}$,

\section{Number of Leaves}

The analysis results showed that treatment $\mathrm{C}$ and $\mathrm{A}$ were not significantly different from $\mathrm{E}$, but significantly different from other treatments. Treatment $\mathrm{C}$ or a mix of Azolla extract of $200 \mathrm{ml} / 1+$ vermicompost $47 \mathrm{~g}+$ Azolla compost $43 \mathrm{~g}+$ husk charcoal $10 \mathrm{~g}$ contained $\mathrm{N}$ and $\mathrm{P}$ elements that can stimulate leaf growth. Increased $\mathrm{N}$ elements will eventually be followed by increased new cell forming materials which will further increase the formation of plant vegetative organs such as plant height and number of leaves. The leaf growth rate shown in Fig. 2 (appendix 1) shows that treatment $\mathrm{E}$ or $\mathrm{AB} \mathrm{MIX}+20 \mathrm{~m}$ husk charcoal and treatment C or Azolla extract $200 \mathrm{ml} / 1+$ vermicompost $94 \mathrm{~g}+$ husk charcoal $10 \mathrm{~g}$ resulted in higher leaf growth rate compared to other treatments.

\section{Leaf Area}

The total leaf area of caisin can be seen in Table 3, showing that Treatment $\mathrm{C}$ was not significantly different with treatment $\mathrm{E}$ but significantly different from other 
treatments. The development of leaf area is comprised of cell expansionand cell division which require nutrients and energy to form new cells. Treatment of Azolla extract 200 $\mathrm{ml} / 1+$ vermicompost $47 \mathrm{~g}+$ Azolla compost $43 \mathrm{~g}+$ husk charcoal $10 \mathrm{~g}$ and treatment of $\mathrm{AB}$ MIX $+20 \mathrm{~g}$ husk charcoal resulted in the broadest leaf area. $\mathrm{N}, \mathrm{P}$ and $\mathrm{K}$ contents on these treatments were able to increase the growth and leaf area of caisin. [13] mentioned that the presence of $\mathrm{P}$ elements can increase the growth of leaf area.

\section{Leaf Color}

Based on the results of leaf color measurement, all the treatments had a similar percentage between $72 \%$ to $78 \%$. Photosynthesis requires chlorophyll, so chlorophyll is generally synthesized on the leaves to capture sunlight [4]. Nutrient content is one factor that can influence the chlorophyll content in leaf; nitrogen is a nutrient content that acts as a constituent of chlorophyll synthesis. High nitrogen content makes the leaves greener and last longer. This is in accordance with the statement of [14] that nitrogen is an essential compounding element of plants and also existed in chlorophyll constituents that making it look green.

\section{CONCLUSION}

1. Effect of organic nutrients in hydroponic wick system on caisin is the same as that of inorganic nutrients in terms of all parameters.

2. The use of a mix of organic nutrients Azolla extract 200 $\mathrm{ml} / 1+$ vermicompost $47 \mathrm{~g}+$ Azolla compost $43 \mathrm{~g}+10$ $\mathrm{g}$ of rice husk charcoal shows the best result in terms of plant height $(25.50 \mathrm{~cm})$, plant fresh weight $(32.83$ grams), plant dry weight (2.1 gram), number of leaves (9.7 leaves) and leaf area $\left(397 \mathrm{~cm}^{2}\right)$.

\section{REFERENCES}

[1] Kurniasih B, Wulandhany F . 2009. Penggulungan daun, pertumbuhan tajuk dan akar beberapa varietas padi gogo pada kondisi cekaman air yang berbeda. Agrivita 31:118-128

[2] K. Aida Rizqanna, "Aplikasi urin ternak sebagai sumber nutrisi pada budidaya selada (Lactuca Sativa) dengan sistem hidroponik humbu," Undergraduate thesis, Department of Agrotechnology, Faculty of Agriculture, Universitas Muhammadiyah Yogyakarta, 2015.

[3] M.A. Hall, "Plant sturucture, function and adaptation," The Macmillan Press London, P. 443, 1976.

[4] B. Lakitan, "Fisiologi pertumbuhan dan perkembangan tanaman," PT Raja Grafindo Persada, Jakarta, 1996.

[5] F. P. Gardner, R. B. Pearce, R. L. Mitchell, "Fisiologi tanaman budidaya," Translator: Herawati Susilo, UI Press, Jakarta, 1991.

[6] A. Zahid, "Manfaat ekonomis dan ekologi daur ulang limbah kotoran ternak sapi menjadi kascing, studi kasus di PT. Pola Nusa Duta," Ciamis, Veterinary Medicine Faculty, Institut Pertanian Bogor, pp. 16. 1994.

[7] J. Sunaryo, "Pertumbuhan dan hasil padi sistem intensifikasi pada berbagai populasi," Undergraduate thesis, Department of Agrotechnology, Faculty of Agriculture, Universitas Muhammadiyah Yogyakarta, 2004.

[8] S.M. Sitompul and Guritno. B, "Analisis pertumbuhan tanaman," Gadjah Mada University Press. Yogyakarta, 1995.
[9] East West Seed, “Tosakan," http://www.panahmerah.id/product/tosakan, 2017.

[10] H. Kunto and N.S. Budiana, "Hidroponik sayuran,” Penebar Swadaya, Jakarta Timur, p. 25, 2014

[11] Tintondp. "Hidroponik Wick system cara praktis pasti panen," Agromedia, Cinajur, pp. 2,4 and 5, 2016.

[12]F. Fuat, "Budidaya caisin (Brassica Juncea L) menggunakan ekstrak teh dan pupuk kascing," Undergraduate thesis, Universitas Sebelas Maret, p. 28, 2009

[13] Wikinson, Geoffrey and Albert. C, "Kimia anorganik dasar, UI Press, Jakarta, p. 463. 1989

[14] Juniar Sirat. "Luas Daun, Kandungan Klorofil dan Laju Pertumbuhan Rumput pada Naungan dan Pemupukan yang Berbeda". Loka Penelitian Kambing Potong. hal 110. 2008 